\title{
International Cooperation in Educating and Training Police: Forwarding ASEAN's Vision 2020 to Combat Non-Traditional Crimes
}

\author{
Hai Thanh Luong \\ LLB, MA (TransCrimPrev), PhD \\ School for Global, Urban and Social Studies \\ Royal Melbourne Institute of Technology (RMIT University)
}

\begin{abstract}
This paper draws a detailed description of overall cross-border crimes that ASEAN region must be faced when forwarding one common communities on 2020 . In order to improving capacity to preventing and combating non-traditional crimes, enhancing international cooperation in education and training for law enforcement agencies is considered as one of the priorities with ASEAN members. Thus, identifying effective models and professional opportunities in this field between Universities/Academies Police plays an important role in regional strategies to fighting transnational organized crime. To some extent, this study will divide into three main parts. Part one introduces briefly the ASEAN's challenges and difficulties in dealing with non-traditional security and its forms of crime must be faced in integrated process with the worldwide. Part two gauges two basically current systems to police education and training around the world and its advantages and disadvantages. Finally, part three will discuss how about perspectives for international cooperation in training for law enforcement agencies to combating non-traditional crimes at ASEAN region in the future.
\end{abstract}

Keywords: Police education and training, non-traditional crime, ASEAN, international police cooperation

\section{INTRODUCTION}

Located in the central region of Asia and the Pacific, the Southeast Asian nations are directly affected by the complicated crimes that originate from countries in the region and in the world. The tendency of globalization and the process of international integration have brought about sizable benefits to countries in the world, but also pose many new challenges and difficulties to law enforcement forces in general, and the police in countries in particular (Hui, 2011). More particularly, regarding to drug trade, it has been spreading out any countries with both visible and invisible operations, even "more nimble, less traceable ways" (Naim, 2006, p. 14). Consequently, as President Barack Obama stated in his October 2011 National Substance Abuse Proclamation that the damage done by drugs is felt far beyond the millions of Americans [and anyone] with diagnosable substance abuse or dependence problems - countless families and communities also live with the pain and heartbreak it causes. Relationships are destroyed; crime and violence blight communities and dreams are shattered. Substance abuse touches every sector of society, straining our health care and criminal justice systems" (INCSR, 2012, p. $14)$.

Furthermore, the variety of transnational organized crime's forms have been increasingly thrived with global, regional, and national' domain via series illegal activities (UNODC, 2010) and their aspirations have become "limitless in both time and space, with no means or ends out of bounds" (Mandel, 2011, p. 17). They have expanded their scopes of activities, taking full 
advantage of the differences in the legal systems and the scientific and technological levels and experiences of the law enforcement organs of countries to commit offences and crimes (Anthony \& Hangzo, 2013). Additionally, the new generations around the world, as known "information and communications technologies (ICTs)", must be faced dizzy changes and developments with both sides, advantages and disadvantages from globalization and regionalization' effects (Dicken, 2011). After nearly two decades, some of concerns was accounted by Balzer (1996) that still questioned for in international law enforcement cooperation, as following:

1) Transportation systems have improved and expanded dramatically, particularly airline and automobile travel; international tourism and business travel are at record levels.

2) Communication systems have improved and expanded most notably satellite and fibre optic telephone and television transmission, FAX transmission, and computer information storage, processing, and transmission.

3) The breakup of the Soviet Union has reduced or eliminated many trade and travel restrictions between East and West, reduced the level of social control within and between many of the former Soviet bloc countries, and made obsolete many countries' Cold War fears and policies.

4) World trade has expanded, including stronger participation by the economies of Eastern Europe, Asia, the Middle East, and the "Third World"; world economic interdependence is now a basic fact of life.

5) Perhaps most significant of all, the world's population has increased, resulting in more crowding, more areas of poverty, disease, and hunger, and large movements of people across national borders.

To date, seemingly, any countries could be faced with potential threat of various crime types, such as environment crime, high-tech crime, piracy, terrorism, transnational crime, money laundering, trafficking in persons, smuggling of migration (UNODC, 2010). ${ }^{1}$ Even the aftermaths of their actions are very serious, not only in a single country, but in many countries (Prenzler, 2012, p. xiv). Hence, in order to reduce and control its threats, enhancing international cooperation among law enforcement forces is considered as one of the priorities with law enforcement agencies of countries all over the world (UNODC, 2012), particularly with police. Acknowledging this circumstance, over the past years, Vietnam has gradually stepped up international cooperation in crime prevention and suppression within bilateral and multilateral frameworks, including ASEANPOL and INTERPOL.

Crime prevention relates directly to development, social wellbeing, and to peace, or what is today often termed "human security." 2 In fact, one of the fundamental principles of the Association of Southeast Asian Nations (ASEAN, 1967) stated in the Bangkok with its Declaration is "strengthening the foundation for a prosperous and peaceful community of Southeast Asian Nations". Deeply, during over 45 years past, ASEAN policies, plans, strategies

\footnotetext{
1 This paper only identifies eight out of new emergent crime as the United Nation of Drugs and Crime collected, expect for trafficking in cultural property and organ trafficking. All of these crimes also will be re-introduced at the Part 3 of the study.

2 To understand "human security" at this paper will be adopted from the final report Human Security Now of Commission on Human Security (2003). Accordingly, it defines as: “...to protect the vital core of all human lives in ways that enhance human freedoms and human fulfilment. Human security means protecting fundamental freedoms - freedoms that are the essence of life. It means protecting people from critical (severe) and pervasive (widespread) threats and situations. It means using processes that build on people's strengths and aspirations. It means creating political, social, environmental, economic, military and cultural systems that together give people the building blocks of survival, livelihood and dignity." (p.4)
} 
and activities still establish and revolve around this principle (Minh, 2013). Transnational crimes have the potential to undermine social order at the nation state level, and, if unchecked, the political, economic and social wellbeing of ASEAN as a whole (Emmers, 2009). In realizing the dangerous threats and risks of transnational organized crime, ASEAN countries have taken concerted efforts to combat such crime since early 1970s with first four-group, Thailand, Malaysia, Indonesia, Philippine and until now with full membership (Emmers, 2003).

Moving forward one Community on 2020, ASEAN has been increasingly concentrating on three main pillars, namely Political-Security, Economic, and Social-Cultural. With one dynamic and integrated community, it brings many advantageous opportunities to sustainable development with various sides (ASEAN, 2013, pp. 2-3). However, absolutely, it also exists and appears potential threats and risks with regional safety and national security when one unlimited border between ASEAN's members created. Therefore, one of the fundamental objectives of Declaration on Combating Transnational Crime of ASEAN is to enhance strengthen regional commitment and capacity to combat transnational crimes which include terrorism, drug trafficking, arms smuggling, money laundering, trafficking in persons and piracy (ASEAN, 2012, pp. 9-10). More particularly, at the Plan of Action to Combating Transnational Crime of ASEAN (2012, p. 20)_ENREF_39, it was identified and focused on specific objectives, including:

1. Develop a more cohesive, regional strategy aimed at preventing, controlling and neutralizing transnational crime;

2. Foster regional cooperation at the investigative, prosecutorial, and judicial level as well as the rehabilitation of perpetrators;

3. Enhance coordination among ASEAN bodies dealing with transnational crime;

4. Strengthen regional capacities and capabilities to deal with sophisticated nature of transnational crime; and

5. Develop sub-regional and regional treaties on cooperation in criminal justice, including mutual legal assistance and extradition.

In order to achieve these above objectives, this Plan prioritises training to improve collaboration and cooperation between ASEAN's Member Countries. There are two pillars in training should be concentrated on:

1. Develop regional training programmes, and conduct regular conferences to enhance existing capabilities in investigation, intelligence, surveillance, detection and monitoring, and reporting.

2. Exchange "best practices" of relevant institutions in ASEAN Member Countries involved in the combat against transnational crime, including transfer of technologies (ASEAN, 2012, p. 22).

However, in fact, the lack of mutual understanding, the differences in customs or legislations, political regimes and cultures and languages as well are practical barriers which have a great influence to the effectiveness of international cooperation in preventing and combating crimes, especially non-traditional crimes (Emmers, 2003, p. 420). In addition, some nations lack laws relating to organized crime, extradition, transfer in prison, and other matters, often leading to distrust between police organizations during employing and cooperating (Roth \& Sever, 2007, p. 42). Furthermore, within the "borderless" (Omae, 1990) and "the World is Flat" (Friedman, 2005) in which, new technologies involving miniature explosive devices, the ease of immigration, and rapid and cheap transportation lead to more complex and dangerous scale that have been requiring "new conceptions of policing" (Roth \& Sever, 2007, p. 43). In other words, facing sophisticated, resistant, and highly motivated terrorist and transnational crime 
threats and many potential barriers and difficulties in countermeasures, police needs to establish "a bureaucratic and hierarchical approach toward a networking morphology" (Gerspacher \& Benoît, 2007, p. 347). Moreover, the dearth of competence of national police authorities, national law, and other institutions and systems, the lack of resources in some cases and the lack of integration of national systems into a regionalized forum, these regional factors have led to gaps and spaces in capacity building initiatives (Gerspacher, 2005, p. 434). More particularly, it was likely to extend policy, training, organizational of national systems, and negotiation of bilateral agreements among other efforts that are established and undertaken by the unlimited contributions from all States in region. Therefore, to some extent, improving and enhancing in international cooperation to educate and train human resource for police should identify one of the initial priorities in policing reforms and its policy between nations.

\section{POLICE TRAINING MODELS IN THE WORLD AND REGION}

Due to different systems of government and law between countries, there are differences in legal structures and law enforcement organization that come to light as a consequence of globalization and the growth of transnational criminal activities (Frost, 1996). In most of the countries, the police force belongs to the state civil servant system in which the trade union plays an important role in protecting police officers' own interests (Loader \& Walker, 1999). Obviously, law enforcement agencies in general and police force in particularly must be "ensure their budgets are used to deliver the best possible outcomes and ensure that their local communities are kept safe from criminals who may operate across force or national boundaries" (Home Office, 2010, p. 23).

In some other countries, police is a part of the armed force, also known as military police. They are refer to a section of the military responsible for policing in both the armed forces and in the civilian population, such as the French Gendarmerie (Bierhals, 2010), the Italian Carabinieri (Paoletti, 2008) and the Portuguese Republican National Guard (OSCE, 2002). Otherwise, they are consider as a section of the military solely responsible for policing the civilian population such as the Romanian Gendarmerie (OSCE, 2001); and as Special Military law enforcement Service, like the Russian Military Police (Nichol, 2011). Therefore, obviously, the training system of each country offers several specific characteristics in terms of training candidates, recruitments, training contents and methods (Frost, 1996). Notably, with natural changes of police work in the early decade of the $21^{\text {st }}$, especially after $11 / 9$ event at the United States of American, it leads to impact considerably on present-day police educating and training (Kratcoski, 2004). In fact, both of field, between education and training, are different objectives and distinct methodologies. According to arguments of Kratcoski (2004), developing and improving the qualification to conceptualize and magnify the theoretical and analytic learning process is one of the basic objectives of police education, while training includes achieving the skills needed to perform the immediate and practical operational tasks to which police are assigned. However, whatever the methods applied, the main purpose of professional development is to prepare police officers to meet the challenges of local policing in a globalized world (Ryan, 2010). To date, there are two types of police training model, namely police education for professional degrees and police education for professional skills. The changing nature of police work in the 21st century is needed to analysed critically and evaluated effectively between advantages and disadvantages of both of these models in order to make police candidates recognized of the "global environment of the information world without borders" during their education and training (Hall, 2002, p. 35). 


\section{Model 1: Policing education for professional degrees at universities/academies}

In this type of education, police officers are trained according to level such as noncommissioned officers at school and college levels; commissioned officers at university level, involving higher levels are for postgraduate of master and doctor of philosophy (Ha Chi, 2006). The learners are provided qualifications that are equivalent to the training levels with various timetables. For example, in Vietnam, the duration of police training at police colleges' level only two years, meanwhile, it is five years with professional program at the people's police university and academy (Phu, 2009). At postgraduate level, the latter will cover and implement, while the former is not supply for learners (Phu, 2006). The countries which have been applying this type of education are ones in the former Soviet Union (Mareninova, 2012), People's Public Security Univeristy of China (2013), the Police Academy of the Czech Republic (2012), South Korea, Taiwan, Panama and some ASEAN countries such as Vietnam, Thailand, Laos, Cambodia, The Philippines, Indonesia and so on.

\section{This model offers basic advantages for candidates}

Learners are systematically provided with basic and comprehensive knowledge in terms of theory (Vodde, 2011). They are also practiced in reality and get with various degrees, including Bachelor of Security Science, Bachelor of Police Science, Bachelor of Law or Bachelor of Administration and so on (Singhsilarak \& Cheurprakobkit, 2007; Thailand Royal Police Cadet Academy, 2006). In addition, learners are likely to gain practical knowledge with regard to law, psychology, politics, economy, sociology and as a result, when graduating from university, police officers are sufficiently flexible and adaptable to work in different police fields (Phu, 2009). Graduates can also continue their study at master or doctoral levels if they except for and succeed apply their application (Das \& Kratcoski, 1999). At the moment, according to review of Kratcoski (2004), some academies and universities provide master and doctoral degrees of police training are the Vietnamese People's Police Academy33, The Lao National Security Academy, The Cambodia Royal Police Academy, Thailand Royal Police Cadet Academy, Kuala Lumpur Police University (Malaysia), The Chinese People's Public Security University, Academies and Police Universities of the Home Affairs of Russia.

\section{Learners must be faced with some main disadvantages by this education model}

The duration of university programs is a major disadvantage where, in Vietnam, students study between three and four years even five years (Phu, 2009). Consequently, it leads to put potential pressures on the management, lecturing, and material facilities such as lecture halls, accommodation, dining rooms for learners. In addition, the training expense is likely to more expensive and exhausted due to investing infrastructures and constructing buildings (Phu, 2006). Furthermore, the training content of this model focuses more on theoretical issues than practical needs, and the training duration for interdisciplinary subjects and professional subjects is limited. Meanwhile, police work is dependent on structural and historical factors as well as on those who work in the police service that be needed to change, innovate, and improve in police education and training (Karp \& Stenmark, 2010, p. 5). Therefore, graduates

\footnotetext{
${ }^{3}$ Currently, at the People's Police Academy of Vietnam is the first institutions training law enforcement agencies in Vietnam to apply "outstanding output" with bachelor's degree. More specifically, with respect of professional program with bachelor of security science, any student must be reached up with "standard criteria" before they graduate. There are seven basis points, including policing professional knowledge, ethical consideration, and English level with TOEFL's score band at 450-500 or relevant languages, information technology's skill, shooting level, martial arts' skills, and driving skills.
} 
from this model are likely to lack of working experience compare with practical needs of society.

\section{Model 2: Policing training for professional skills at colleges/academies}

Police Vocational Training model aims at providing knowledge and policing skills for those who are newly recruited to the police force. The learners are much diversified including those who have finished high school, professional colleges or universities. The short-term training courses provide practice and students are allowed to work immediately after that. Some countries applying this model are the United Kingdom, the United States of America, Japan, France, Australia, Brunei, Myanmar, and so on.

Geopolitically, close similarities with the United Kingdom and Australia, in the USA, with a multi-combined policing system federal, state, and local police organizations build and create their distinct training program and the content and quality of basic training varies enormously (Travis \& Langworthy, 2007). General speaking, federal law enforcement agencies and each state legislature institute the basic training frameworks and standards that must be fixed with qualify for a policing requirement (Chappell, 2008). However, to some extent, Kratcoski (2004, p. 17) notes that the actual training can be supported and designed by a training academy administered "by the police agency, by a private training facility, by a state-wide police training academy, or occasionally by a local college or university that has established a program that combines basic training with academic credit that could lead to a higher education degree". Furthermore, police agencies are likely to connect and contract with colleges/universities/academies to provide some specialized training (Chappell, 2008).

Regarding to curriculum, particularly, the duration of training is combined flexibly between official learning time at colleges and practice at communities and during this time, students are provided with basic knowledge and police skills and behaviours in public (Trofymowych, 2008). The fact this training model mainly focuses on police skills, therefore material facility equipment such as lecture halls, practice areas are taken into consideration. For example, interview rooms are equipped with audio and video recorders and chairs and table are arranged as in the real interview rooms in police stations. Students and lecturers have to act as an interviewer and an interviewee like in a real interview. Some colleges also build up a residential area where there are pubs, banks, restaurants, discotheque for students to practice. After a 6 month practicum, students will be sent to police stations where they have to study at a distance and also under the supervision and guidance of at least an experienced police officer who is able to train others (most of the supervisors are trained how to supervise and guide police students to practice). Police students can only go back to the police college to take part in the graduation exam when assessed by the supervisor to meet all requirements and to be able to become police officers. If not, they are only granted a certificate to certify the attendance of a police-training course. ${ }^{4}$

\section{Advantages of policing training for professional skills}

This model concentrates on training police skills. The time spending on theory learning is less than in practical training, hence the professional skills of police officers, so the graduates are very quickly adaptive to the work of criminal prevention and combating. In addition, recruits are much diversified criteria, including those employed and unemployed. Furthermore, the

\footnotetext{
4 This example is a part practice's scenario out of the standard curriculum of Faculty of Criminal Investigation, the People's Police Academy of Vietnam (internal publication only with Vietnamese version)
} 
additional training course is usually short and therefore learners can do both working and learning, it is easy for them to arrange job to study and it does not influence much on the whole work of the police station. However, this model may only be suitable for advanced education countries where link between universities and colleges are close and the concept of qualification is not too "heavily" considered.

\section{Disadvantages of this training model}

One limited point of this short-term model is graduators only recognized as certificate, not undergraduate/postgraduate degree as the first model after they graduated their course. In other words, although "professionalization" is not merely about police officers having an academic qualification, but much more critically it is about the requirement for them to support what may be better termed a "professional habitués" (Heslop, 2010). Besides that, with the short-term model, the flexible requirements of curriculum are higher due to practical scenario and changeable circumstances often not stable. In other words, textbook and material providing this model as well as changes to program, the rebalancing of skills and knowledge where student officers are taught, have to update frequently to fix up with real needs of police force (Wood \& Stephen, 2009).

\section{ORIENTED PROPOSALS TO ENHANCE INTERNATIONAL COOPERATION IN POLICE TRAINING AT ASEAN REGION}

As analysed above, each police-training model appears some strong points and the selection of each training model is based on the particular conditions, and on material facilities and training requirements of each country. However, whatever model applied, the need to make international cooperation in ASEAN region becomes very clear and urgent when appearing non-traditional crimes with their serious threats in order to meet the demands of modern society, more particularly forward on 2020 with ASEAN's vision.

In some recent years, beside the quick social and economic development, some non-traditional crimes have appeared and increased such as transnational crimes, foreign crimes, hi-tech crimes, environmental crimes, and crimes on the sea. Non-traditional crimes happen in many fields of life with many sophisticated and cunning criminal tricks and techniques, criminals have taken advantage of the lack and loophole in legislations and state policies, social and economic management in order to commit these crimes. The trend of integration and globalization is happening all over the world. It can be said that no countries may stand outside this trend whatever fields are mentioned: economy, politics or security. The globalization trend offers many disadvantages but it brings countries close to one another; the achievements of science, technology, and culture are not private properties of any country or continent in the $21^{\text {st }}$ century. It was also required to enhance and improve international and regional cooperation against non-traditional crimes between law enforcement agencies in both theories and practices' fields. In fact, in accordance with the development of the economy there are emerge many kinds of non-tradition crimes with its potential threats, such as transnational human trafficking, drug trafficking; theft of cars and antiquities; and high-tech crimes. Consequently, it is needed to cooperate in researching, analysing and establishing an integrated training to educate law enforcement office where provides general conferences and programmes to exchange and build legislative frameworks, practical strategies, and regional institutions.

Implementation of the initiative of the 29th ASEAN Chiefs of Police Meeting (ASEANAPOL) held in Hanoi in May 2009, under the consent of leadership of the Vietnamese Ministry of Public Security, the People's Police Academy cooperated with the Vietnam's Interpol Office to host the 
first ASEANAPOL police training cooperation meeting on $8^{\text {th }}$ December 2010 in Hanoi. This conference focused on main theme - "Police training cooperation before an increase of nontraditional crimes in the ASEAN region". It was considered as one important milestones of international cooperation in police training at the Southeast Asian region. At the meeting, delegates introduced and discussed their police training methods; share their experiences, achievements of training public security in each nation and in the ASEAN region; clarified the issues on non-traditional crimes; from that basis to identify new directions on police training content and method to meet the demand for more action against crime today. During the opening the session on $8^{\text {th }}$ December, Vietnam's Deputy Minister of Public Security Lieutenant General Bui Van Nam, stressed on the urgent need for countries in the region to fight crime, including non-traditional crimes through improving regional cooperation in control crime. Particularly, focusing on exchange and identify a suitable program in education and training for law enforcement agencies between ASEAN countries should be recognized as one of the significant priorities in ensuring stability and peace in each regional nation. At this conference, almost of delegations supported and approved to strengthen joint police training in the region, including the exchange of cadets between police training colleges, short-term training courses and training programmes with partner countries. To some extent, though this conference is an initiated of Vietnam Police Force, it will forward long-term aims that strengthen cooperation amongst the region's police forces and offer an opportunity to increase cooperation in the ASEAN. It also serves as a forum for ASEAN nations to present their police training methods, share their experiences, achievements and challenges in the area, which will help to improve police forces across ASEAN and meet the demand for more action against crime throughout the region. As a result, all attended delegations strongly believed that the police academies and colleges in ASEAN countries should be concentrated on educated cooperation and trained collaboration more effective in process of forwarding on 2020. In order to achieve this expectation, there are some main recommendations that were shown as following:

Firstly, between police academies/colleges in the region need to sign memorandum on police training and carrying out the exchange of lecturers and students of their institutions. By doing this, it leads to diversified methods to not only exchanging information and materials used for the training, but also enhancing policing skills for police lecturers and students. In the future, furthermore, proposing ASEAN police colleges and academies sign with memorandum to recognize qualification of each country to easier in exchange education are considered as one of the prioritized issues. In this regard, it should have the interest and cooperation from the area of the Institute/School Police of some developed countries such as Singapore Police, Royal Thai Police, and Malaysia Police.

Secondly, if this above perception can be done, ASEAN's police training institutes should be forward establishing a police training centres. It covers central responsibilities to organize training course for police officers and to share their information and experience between countries on preventing and combating non-traditional crime. In addition, it should be focused on main aim that is to improve the effectiveness and co-operation between the competent authorities of the member states primarily by sharing and pooling intelligence to prevent and combat serious international organized crime. For instance, with respect to illicit narcotics trafficking' concerns at the Southeast Asian region, it is necessary to develop training programs counter-narcotic trafficking through exchange information in terms of new routes and its organizational structure and modus operandi within regional and national scale. By doing this, it is likely to assist police candidate to comprehensive understanding about the nature of transnational drugs trafficking in our regions and in addition, to share information in order to improve capacity and coordination between law enforcement institutions at the national level 
to investigate this crime. In other words, to some extent, its mission is to make a significant contribution to the ASEAN's law enforcement efforts targeting non-traditional security crimes.

Thirdly, as the Author mentioned above, in ASEAN community is existing two police training models. Each model appears many strong points but also weak points. One notable thing should be thought that every country would have multilateral and bilateral exchange in order to perfect each model. Initially, if ASEAN's Police Training Centre be supported and employed, it should concentrate on short-term courses and exchange trainees between police universities/academies. With the purposes for improving and enhancing international and regional cooperation to combat non-traditional crimes, between universities and academies should establish the curriculum on the needs of ASEAN police and its applications into research, educate and training. Through annual the ASEAN police training cooperation meeting, this theme will be introduced, discussed, and exchanged in order to identify the prioritized fields to focus on. In recent meeting at Thailand, March 2014, the Meeting has developed priorities on the training needs of ASEANPOL with main subjects, including hi-tech crime, human trafficking, drug trafficking, transnational crime, and pharmaceutical crime. After all, when identified these priorities' targets, this Centre have to play manage and share' roles between institutions in regions where lectures and cadets are likely to exchange resource materials and police professional skills.

All above are some expecting fields of police training cooperation in ASEAN region in the period of increasing non-traditional crime which strongly believe we need to take serious attention in the soon years. In order to combine flexibly between theoretical and practical issues in educating and training police, each country in the region needs to priorities training cooperation to enhance the effective in combating crimes for "the peace, prosperity and thriving of an ASEAN".

\section{ACKNOWLEDGEMENT}

The author would like to impress my respectful and grateful to my PhD's principal supervisor, A/Prof Paul Battersby, Deputy Dean, Global Studies, School for Global, Urban, and Social Science, RMIT University, Melbourne, Victoria, Australia who he supported and commended this paper during prepare.

\section{References}

Anthony, M. C., \& Hangzo, P. K. K. (2013). Transnational Crime. In Mely Caballero-Anthony and Alistair D. B. Cook (Ed.), Non-Traditional Security in Asia: Issues, Challenges and Framework for Action (pp. 234-267). Singapore: Institution of Southeast Asian Studies.

The ASEAN Declaration (Bangkok Declaration) (1967).

ASEAN. (2012). ASEAN Documents on Combating Transnational Crime and Terrorism. Jakarta, Indonesia: Public Outreach and Civil Society Division.

ASEAN. (2013). On Track to ASEAN Community 2020: ASEAN Annual Report 2012-2013. Jarkata, Indonesia: ASEAN Secretariat.

Balzer, A. J. (1996). International Police Cooperation: Opportunities and Obstacles. In M. Pagon (Ed.), Policing in Central and Eastern Europe: Comparing Firsthand Knowledge with Experience from the West. Ljubljana, Slovenia: College of Police and Security Studies [Online] available at https://www.ncjrs.gov/policing/int63.htm.

Bierhals, G. (2010). Towards the Freedom of the Operating System: the French Gendarmerie goes for Ubuntu.

Chappell, A. T. (2008). Police Academy Training: Comparing across Curricula. Policing: An International Journal of Police Strategies \& Management, 31(1), 36-56. 
Das, D. K., \& Kratcoski, P. C. (1999). International police co-operation: a world perspective. Policing: An International Journal of Police Strategies \& Management, 22(2), 214-242.

Dicken, P. (2011). Global Shift: Mapping the Changing Contours of the World Economy (6 $6^{\text {th }}$ ed.). New York, the U.S.: The Guilford Press.

Emmers, R. (2003). ASEAN and the securitization of transnational crime in Southeast Asia. The Pacific Review, 16(3), 419-438. doi: 10.1080/0951274032000085653

Emmers, R. (2009). The threat of transnational crime in Southeast Asia: drug trafficking, human smuggling and trafficking, and sea piracy UNISCI Discussion Papers (pp. 1-11): Research Unit on International Security and Cooperation (UNISCI).

Friedman, T. L. (2005). The World is Flat: A Brief History of the Twenty-First Century. New York, the U.S.: Farrar, Straus and Giroux.

Frost, T. B. (1996). The Case for International Police Cooperation on Training Issues. Paper presented at the Policing in Central and Eastern Europe: Comparing Firsthand Knowledge with Experience from the West, Ljubljana, Slovenia.

Gerspacher, N. (2005). The Roles of International Police Cooperation Organizations. European Journal of Crime, Criminal Law \& Criminal Justice, 13(3), 413-434. doi: 10.1163/1571817054604100

Gerspacher, N., \& Benoît, D. (2007). The Nodal Structure of International Police Cooperation: An Exploration of Transnational Security Networks. Global Governance, 13(3), 347-364.

Ha Chi. (2006). The People's Police Academy: 15 years of Postgraduate Training. Social Order Science and Education Magazine, Vol 7. http://hvcsnd.edu.vn/en/Acedemy/History/134/1776/The-Peoples-Police-Academy15-year-of-postgraduate-training.aspx

Hall, S. (2002). Police Training and Education: A Representative Global Perspective. Paper presented at the the Ninth Annual Meeting of the International Police Executive Symposium, Antalya, Turkey.

Heslop, R. (2010). 'They didn't treat us like professionals': a case study of police recruits trained at a university. Paper presented at the Professional lifelong learning: Critical perspectives on professional learning conference. University of Leeds.

Home Office. (2010). Policing in the 21st Century: Reconnecting Police and the People. London, U.K.: Home Office. Hui, K. B. (2011). Speech Remark at 80th INTERPOL General Assembly viewed 11 August 2013.

INCSR. (2012). International Narcotic Control Strategy Report Volume 1: Drug and Chemical Control (Vol. 1 (Drug and Chemical Control)). Washington, D.C, the U.S.: United states Department of State, Bureau for International Narcotics and Law Enforcement Affairs.

Karp, S., \& Stenmark, H. (2010). Learning to be a police officer. Tradition and change in the training and professional lives of police officers. Police Practice and Research, 12(1), 4-15. doi:

10.1080/15614263.2010.497653

Kratcoski, P. C. (2004). Police Education and Training in a Global Society: Guest Editor's Introduction. Police Practice and Research, 5(2), 103-105. doi: 10.1080/156142604200190252

Loader, I., \& Walker, D. (1999). Governing policing in the 21st Century. Criminal Justice Matters, 38(1), 9-11.

Mandel, R. (2011). Dark Logic: Transnational Criminal Tactics and Global Security. Stanford, California: Stanford Univeristy Press.

Mareninova, P. S. (2012). Issues Facing Legal Education in Russia: Some Problems and Solutions. from UCLA International Institute

Minh, L. L. (2013). Moving ASEAN Forward, Strenthening Community Building, Special address by Secretary General of ASEAN at the 10 ${ }^{\text {th }}$ ASEAN Leadership Forum, 18 July 2013.

Naim, M. (2006). Illicit: How Smugglers, Traffickers, and Copycats are Hijacking the Global Economy. New York, the U.S.: Anchor Books.

Nichol, J. (2011). Russian Military Reform and Defense Policy. Washington D.C, the U.S.: CRS Report for Congress.

Omae, K. (1990). The Borderless World: Power and Strategy in Interlinked Economy - Management Lessons in the New Logic of the Global Marketplace. New York, the U.S.: Harper Collins Publishers, Inc. 
OSCE. (2001). Policing Profiles of Participating and Partner States (Romania).

OSCE. (2002). Policing Profiles of Participanting and Partner States.

Paoletti, D. C. (2008). A Military History of Italy. Westport, CT, the U.S.: Praeger

People's Public Security Univeristy of China. (2013). School Profile.

Phu, T. N. (2006). Contents, Training Program of Regular Univeristy Level in People's Police Academy. Retrieved 15 April, 2006, from http://hvcsnd.edu.vn/en/Training/Professional-Training/171/1775/CONTENTSTRAINING-PROGRAM-of-regular-university-level-in-Peoples-Police-Academy.aspx

Phu, T. N. (2009). Undergraduate Training Programme at the People's Police Academy. Retrieved 28 September, 2009, from http://hvcsnd.edu.vn/en/Training/Professional-Training/171/1775/CONTENTS-TRAININGPROGRAM-of-regular-university-level-in-Peoples-Police-Academy.aspx

Prenzler, T. (Ed.). (2012). Policing and Security in Practice: Challenges and Achievements. Hampshire, U.K.: Palgrave MacMillan.

Roth, M. P., \& Sever, M. (2007). Barriers to International Police Cooperation in the Age of Terrorism. In H. Durmaz, B. Sevinc, A. S. Yayla \& S. Ekici (Eds.), Understanding and Responding to Terrorism (pp. 42-56). Amsterdam, the Netherlands: IOS Press.

Ryan, C. M. (2010). "Tough, Loyal, Reputable": D/discourse and Subcultures in Vocational Police Training. the International Journal of Training Research, 4.

Singhsilarak, J., \& Cheurprakobkit, S. (2007). Police Education and Training in Thailand. In P. C. Kratcoski \& D. K. Das (Eds.), Police Education and Training in a Global Society (pp. 57-71). Lanham, MD, the U.S.: Lexington Books.

Thailand Royal Police Cadet Academy. (2006). Curriculum of Royal Police Cadet Program.

the Police Academy of the Czech Republic. (2012). Study Programme and Education at the Police Academy of the Czech Republic. 1 April 2008

Travis, L. F., \& Langworthy, R. H. (2007). Policing in America: A Ballance of Forces. the U.S.: Pearson/Prentice Hall.

Trofymowych, D. (2008). Police Education Past and Present: Perceptions of Australian Police Managers and Academics. Flinders Journal of Law Reform, 10, 419-433.

UNODC. (2010). The Globalization of Crime: A Transnational Organized Crime Threat Assessment. Vienna, Austria: United Nations Publication.

UNODC. (2012). Manual on Mutual Legal Assistance and Extradition. New York, the U.S.: United Nations Publication.

Vodde, R. F. (2011). Organizatioinal Paradigms for Police Training and Education. International Police Training Journal, 17-21(2).

Wood, D. A., \& Stephen, T. (2009). The future of initial police training: a university perspective. International Journal of Police Science \& Management, 11(3), 294-305. doi: 10.1350/ijps.2009.11.3.131 